\title{
Acute effect of a variable pulse width Nd:YAG laser combined with hematoporphyrin monomethyl ether-mediated photodynamic therapy on a cockscomb model of nevus flammeus
}

\author{
Ke Ma ${ }^{1, A, F}$, Lvjun Yang ${ }^{2, B, E}$, Mingde Lia0, ${ }^{1, B}$, Yi Qin ${ }^{3, C}$, Chao Luo ${ }^{4, D}$, Lina Lin ${ }^{5, E}$, Danyan Ye ${ }^{2, D}$ \\ 1 Department of Plastic \& Cosmetic Surgery, The First Affiliated Hospital of Guangxi Medical University, Nanning, China \\ ${ }^{2}$ Research Center for Translational Medicine, Shantou University Medical College, China \\ ${ }^{3}$ Department of Anesthesiology, The First Affiliated Hospital of Guangxi Medical University, Nanning, China \\ ${ }^{4}$ School of Life Science, Central South University, Changsha, China \\ ${ }^{5}$ Department of Gynecology, The First Affiliated Hospital of Guangxi Medical University, Nanning, China \\ A - research concept and design; $\mathrm{B}$ - collection and/or assembly of data; $\mathrm{C}$ - data analysis and interpretation; \\ $\mathrm{D}$ - writing the article; $\mathrm{E}$ - critical revision of the article; $\mathrm{F}$ - final approval of the article
}

\section{Address for correspondence \\ $\mathrm{Ke} \mathrm{Ma}$ \\ E-mail: 1037579997@qq.com}

\section{Funding sources \\ This work was supported by the National Natural Science Foundation of China (grant No. 81472054) and the Guangxi Science and Technology Major Project (grant No. AA17204085).}

\section{Conflict of interest}

None declared

Received on March 25, 2020

Reviewed on March 30, 2020

Accepted on August 11, 2020

Cite as

Ma K, Zhao J, Yang L, et al. Acute effect of a variable pulse width Nd:YAG laser combined with hematoporphyrin monomethyl ether-mediated photodynamic therapy on a cockscomb model of nevus flammeus. Adv Clin Exp Med. 2020;29(12):1425-1431. doi:10.17219/acem/126300

DOI

10.17219/acem/126300

\section{Copyright}

Copyright by Author(s)

This is an article distributed under the terms of the

Creative Commons Attribution 3.0 Unported (CC BY 3.0)

(https://creativecommons.org/licenses/by/3.0/)

\section{Abstract \\ Background. Nevus flammeus (NF) is a congenital vascular malformation.}

Objectives. To investigate the acute effect of a variable pulse width Nd:YAG laser combined with hematoporphyrin monomethyl ether (HMME)-mediated photodynamic therapy (PDT) on a cockscomb model of NF.

Material and methods. Forty-two leghorn roosters were randomly divided into the following 7 groups: group A1 (treated with HMME-mediated PDT; energy density of $75 \mathrm{~J} / \mathrm{cm}^{2}$ ), group A2 (treated with HMMEmediated PDT; $125 \mathrm{~J} / \mathrm{cm}^{2}$ ), group A3 (treated with HMME-mediated PDT; $150 \mathrm{~J} / \mathrm{cm}^{2}$ ), group A4 (treated with HMME-mediated PDT; $175 \mathrm{~J} / \mathrm{cm}^{2}$ ), group B (treated with a variable pulse width Nd:YAG laser), group C (treated with a variable pulse width Nd:YAG laser and HMME-mediated PDT), and group D (the control group). Changes in the cockscomb tissues were observed visually and microscopically on days 1,3,7, and 14 after treatment. The capillary reduction and the ratio of collagen type I to type III were examined.

Results. The response rate was higher in groups A3 and A4 than in group B. In group A, a higher energy density resulted in a higher response rate and a greater capillary reduction ( $p<0.05$ for all). However, we concluded that PDT at an energy density of $175 \mathrm{~J} / \mathrm{cm}^{2}$ is not suitable for treating NF, as severe tissue damage, markedly lower capillary numbers, and markedly higher collagen type l:Ill ratios were observed in the cockscombs treated at this energy density; instead, $150 \mathrm{~J} / \mathrm{cm}^{2}$ may be a more appropriate energy density. Moreover, HMME-mediated PDT at $150 \mathrm{~J} / \mathrm{cm}^{2}$ combined with a variable pulse width Nd:YAG laser achieved better treatment outcomes than PDT or a variable pulse width Nd:YAG laser alone ( $p<0.05$ for both).

Conclusions. Compared to PDT or a variable pulse width Nd:YAG laser alone, the combination of the 2 therapies achieved a better acute effect in treating a cockscomb model of $\mathrm{NF}$, and $150 \mathrm{~J} / \mathrm{cm}^{2}$ may be a suitable energy density for PDT.

Key words: photodynamic therapy, laser, nevus flammeus, hematoporphyrin monomethyl ether 


\section{Introduction}

Nevus flammeus (NF), also known as port-wine stain, is a congenital vascular malformation characterized by ectasia of capillaries and venules; it often occurs in dermal papillary and reticular layers. ${ }^{1,2}$ The disease does not resolve without treatment, and the incidence rate is about $0.4 \%$ in children. ${ }^{3,4}$ Treatment options for NF include laser therapy, cryotherapy and surgery. ${ }^{5-7}$ A pulsed dye laser, which is the most widely used therapy for NF, can achieve good results but may cause irreversible vessel injury, thereby increasing the risk of purpura. Moreover, there may be a recurrence after pulsed dye laser therapy, and it is ineffective in some NF cases. ${ }^{7,8}$ Therefore, it is essential to find a more effective method for the treatment of NF.

In recent years, photodynamic therapy (PDT) has been considered a good method for treating NF. ${ }^{9}$ In this therapy, photosensitizers can accumulate selectively in the vascular endothelial cells, and the recurrence rate is low. The greatest advantage of PDT is that it has high selectivity in the target tissue. Some studies have demonstrated that hematoporphyrin monomethyl ether (HMME) displays characteristic absorption peaks in multiple wavelengths, and a 532-nm laser is often used in PDT for treating NF. ${ }^{10,11}$ Therefore, a 532-nm continuous laser was chosen for our experiment. During PDT, the capillary malformation is targeted by substances generated from the reaction between the laser and photosensitizers. This therapy can be applied in large-area skin damage and offers a low recurrence rate. ${ }^{12}$ However, most of the studies to date investigated only the effect of PDT on patients in clinical practice and no effective animal experiments were carried out; moreover, the energy densities applied in those studies were empirical doses. The effectiveness of PDT in the treatment of NF has been demonstrated in many studies. ${ }^{5,9,11,13}$ Different energy densities $\left(75 \mathrm{~J} / \mathrm{cm}^{2}, 100 \mathrm{~J} / \mathrm{cm}^{2}\right.$ and $\left.150 \mathrm{~J} / \mathrm{cm}^{2}\right)$ were investigated in some of these studies, but the effects of different energy densities on the treatment outcomes were not thoroughly compared. Therefore, in order to find a suitable energy density for treating NF, we compared 4 energy densities in our experiments. It has been revealed that a variable pulse width Nd:YAG laser can achieve good efficacy in treating some skin diseases. ${ }^{14}$ In this therapy, a 532-nm wavelength is often used to treat NF, as a laser at this wavelength can deeply penetrate the skin, cause a large area of thermal damage and achieve good coagulation; the effect of a variable pulse width Nd:YAG laser at a wavelength of $532 \mathrm{~nm}$ is especially noteworthy in the management of deep vascular malformation. ${ }^{15,16}$ However, no other study has been performed on the effect of combined variable pulse width Nd:YAG laser and PDT. Therefore, in this study, we investigated the effect of the combined use of the 2 methods and compared the efficacy of such use to the efficacy of a variable pulse width Nd:YAG laser or PDT alone.

\section{Material and methods}

\section{Study subjects}

Forty-two leghorn roosters (age: 8-9 months; weight: approx. $3 \mathrm{~kg}$ ) were chosen as subjects. The cockscombs (thickness: 7-9 $\mathrm{mm}$ ) were ruddy and without damage, necrosis or ulcers. The subjects were divided into the following 7 groups: group A1 (treated with HMME-mediated PDT; an energy density of $75 \mathrm{~J} / \mathrm{cm}^{2}$ ), group A2 (treated with HMME-mediated PDT; $125 \mathrm{~J} / \mathrm{cm}^{2}$ ), group A3 (treated with HMME-mediated PDT; $150 \mathrm{~J} / \mathrm{cm}^{2}$ ), group A4 (treated with HMME-mediated PDT; $175 \mathrm{~J} / \mathrm{cm}^{2}$ ), group B (treated with variable pulse width Nd:YAG laser), group C (treated with variable pulse width Nd:YAG laser and HMME-mediated PDT), and group D (the control group). The study was approved by the Animal Ethics Committee of our hospital.

The cockscombs of the leghorn roosters met the criteria for the disease model of NF. ${ }^{17}$

\section{Treatment methods}

\section{Photodynamic therapy}

The HMME is the most commonly used photosensitizer in PDT. For the treatment in our study, HMME (FudanZhangjiang Bio-Pharmaceutical, Shanghai, China) was diluted with normal saline solution $(10 \mathrm{mg} / \mathrm{mL} / \mathrm{kg})$. The subjects received chloral hydrate $(2 \mathrm{~mL} / \mathrm{kg})$ orally for anesthesia, and the experimental area on the left side of the comb was marked in a circle with a diameter of $1.5 \mathrm{~cm}$. The HMME was then injected intravenously into the root of the chicken wings in group A, and laser radiation with a power density of $150 \mathrm{mw} / \mathrm{cm}^{2}$ was applied to the experimental areas. During the radiation, both the experimental and nonexperimental areas were covered. The energy densities in groups A1, A2, A3, and A4 were $75 \mathrm{~J} / \mathrm{cm}^{2}, 125 \mathrm{~J} / \mathrm{cm}^{2}$, $150 \mathrm{~J} / \mathrm{cm}^{2}$, and $175 \mathrm{~J} / \mathrm{cm}^{2}$, respectively.

\section{Variable pulse width Nd:YAG laser}

Before applying the variable-pulse frequency-doubled Nd:YAG (532 nm) laser, the subjects received chloral hydrate $(2 \mathrm{~mL} / \mathrm{kg}$ ) orally for anesthesia, and the experimental areas on the combs were marked in the same way as that in the PDT groups. The energy density was $20 \mathrm{~J} / \mathrm{cm}^{2}$, the pulse-width was $10-50 \mathrm{~ms}$ and the spot diameter was $8 \mathrm{~cm}$.

\section{Combination therapy}

After comparing the effects in the 4 PDT groups, we chose $150 \mathrm{~J} / \mathrm{cm}^{2}$ as the most suitable energy density and applied it with the variable pulse width Nd:YAG laser for the combination therapy. The PDT was first conducted, followed by variable pulse width Nd:YAG laser treatment 10 min later. The 2 procedures were carried out in the same way as described above. 


\section{Outcome measures}

\section{Main outcome measures}

On days 1, 3, 7, and 14 after treatment, samples from the experimental areas of the combs were collected in each group for visual and microscopic inspection, and the nonexperimental area was used as a control. The blood capillaries in the combs were observed under a microscope, and the percentage decrease of the capillary number was calculated with the following formula: percentage decrease of the capillary number $=$ (the number of capillaries before treatment - the number of capillaries after treatment)/ the number of capillaries before treatment $\times 100 \%$.

\section{Secondary outcome measures}

On day 14 after treatment, 5 fields in the experiment area of each comb were randomly picked and drilled for immunohistochemistry staining to examine the levels of collagen types I and III. The samples were fixed with $10 \%$ formaldehyde, sectioned after paraffin embedment, and then dewaxed and hydrated. After antigen retrieval, the samples were blocked with serum and incubated with primary antibodies to collagen types I and III. Next, the samples were incubated with the secondary antibodies after rewarming. Then, they were stained with DAB followed by counterstaining with hematoxylin. The sections were then sealed for observation, and the ratio of collagen type I to type III were calculated.

The response rate in each group was observed and classified into 5 levels as listed in Table $1 .^{18}$ The total response rate $=$ the total number of samples with response rate in levels 1,2 and 3/the total number of samples $\times 100 \%$.

Adverse reactions in each group such as pigmentation, blistering and scar formation were recorded 14 days after treatment.

\section{Statistical analysis}

SPSS v. 19.0 software (IBM Corp., Armonk, USA) was used for the statistical analysis. The measurement data is expressed as means \pm standard deviation (SD). Comparison between 2 groups was conducted using a t-test for independent samples. Measurement data at different time points between the 2 groups were compared with repeatedmeasures analysis of variance (ANOVA) and a Bonferroni post hoc test. A p-value $<0.05$ was considered to indicate a statistically significant difference.

\section{Results}

\section{Results of visual inspection}

After treatment, the color and morphology remained the same in the combs of group D and on the right side of the combs (opposite to the experimental side) in other groups. In contrast, changes were observed in the experimental areas of combs in groups A, B and C. In groups A1-4, the higher energy density resulted in a better clearance of NF. However, the energy density in group A4 was not optimal, as scars were formed on the combs in this group 14 days after treatment. Therefore, we chose the energy density from group A3 for PDT in the combination therapy. The results showed that the outcome in group $\mathrm{C}$ was much better than that of the other groups. In group $C$, 14 days after treatment, marked blanching was observed in some areas and no noticeable scars had formed (Table 2).

\section{Results of microscopic observation}

On days $1,3,7$, and 14 after treatment, the combs in each group were observed under a microscope. Prior to the treatment, the structure of the stratum corneum and the dermis was intact in each group; however, changes were observed after treatment in the blood vessels in the experimental areas of groups A, B and C, whereas the combs in group $\mathrm{D}$ and the right side of the combs in other groups remained unchanged. As with the results of the visual inspection, good clearance of NF was achieved in group A4, but proliferative collagen fibers, which could lead to scars, were observed in this group. Thus, the energy density from group A3 was chosen for the combination therapy. Fourteen days after treatment in group $\mathrm{C}$, the capillaries had almost disappeared, the epidermis had thickened, no blisters had formed, and the results of the treatment were much better than that of other groups (Table 3).

\section{Capillary reduction in each group}

Compared to group D at each time point, the other groups had a higher percentage of decrease in capillary number ( $p<0.05$ for all), suggesting that the treatment in these groups may have damaged the blood vessels. In groups A1-4, we found that a higher energy density resulted in a greater percentage of decrease in capillary number. Moreover, compared to groups $B$ and $A 3$, group $C$ had a greater percentage decrease in capillary number ( $<0.05$ for both; Table 4).

Table 1. Response rate level

\begin{tabular}{|l|c|c|c|c|}
\multicolumn{1}{|c|}{ Variable } & $\begin{array}{c}\text { Level 1: } \\
\text { Excellent response }\end{array}$ & $\begin{array}{c}\text { Level 2: } \\
\text { Good response }\end{array}$ & $\begin{array}{c}\text { Level 3: } \\
\text { Fair response }\end{array}$ & $\begin{array}{c}\text { Level 4: } \\
\text { Poor response }\end{array}$ \\
\hline $\begin{array}{l}\text { Percentage of NF } \\
\text { clearance }\end{array}$ & $80-100 \%$ & $60-79 \%$ & $40-59 \%$ & $20-39 \%$ \\
\hline
\end{tabular}

NF - nevus flammeus. 
Table 2. Results of visual inspection in each group

\begin{tabular}{|c|c|c|c|c|c|}
\hline Group & $\begin{array}{c}\text { Before } \\
\text { treatment }\end{array}$ & 1 day after treatment & 3 days after treatment & 7 days after treatment & 14 days after treatment \\
\hline Group A1 & \multirow{7}{*}{$\begin{array}{l}\text { The comb was } \\
\text { ruddy and intact }\end{array}$} & $\begin{array}{l}\text { No noticeable edema was } \\
\text { observed. The skin color } \\
\text { in the experimental area } \\
\text { was darker compared with } \\
\text { the surrounding area }\end{array}$ & $\begin{array}{l}\text { The skin was slightly } \\
\text { yellowish-white. No skin } \\
\text { damage was observed. }\end{array}$ & $\begin{array}{c}\text { The blanching became } \\
\text { more noticeable. }\end{array}$ & $\begin{array}{l}\text { The blanching decreased, } \\
\text { and the color in part } \\
\text { of the experimental area was } \\
\text { restored to normal. }\end{array}$ \\
\hline Group A2 & & $\begin{array}{c}\text { Mild edema was observed. } \\
\text { Part of the skin was slightly } \\
\text { purplish-red. }\end{array}$ & $\begin{array}{c}\text { Edema was gone. Evident } \\
\text { blanching was observed } \\
\text { in part of the experimental } \\
\text { area. }\end{array}$ & $\begin{array}{l}\text { The purplish-red color } \\
\text { faded in some areas. } \\
\text { The blanching became } \\
\text { more evident. }\end{array}$ & $\begin{array}{l}\text { The blanching decreased, and } \\
\text { the skin color became darker } \\
\text { compared with the surrounding } \\
\text { area and was not restored } \\
\text { to normal. }\end{array}$ \\
\hline Group A3 & & $\begin{array}{l}\text { Moderate edema occurred. } \\
\text { Evident purplish-red } \\
\text { was observed in part } \\
\text { of the experimental area. }\end{array}$ & $\begin{array}{l}\text { The edema reduced } \\
\text { partially, and the purplish- } \\
\text { red color faded slightly. }\end{array}$ & $\begin{array}{c}\text { The edema decreased } \\
\text { significantly. } \\
\text { The blanching } \\
\text { was noticeable } \\
\text { in the experimental } \\
\text { area. }\end{array}$ & $\begin{array}{l}\text { The edema was gone. } \\
\text { The blanching decreased } \\
\text { slightly. Thin crust was formed } \\
\text { on the skin. No blister or scar } \\
\text { was formed. }\end{array}$ \\
\hline Group A4 & & $\begin{array}{l}\text { Severe edema occurred. Part } \\
\text { of the skin was purplish- } \\
\text { black. Blister was formed }\end{array}$ & $\begin{array}{c}\text { The edema was } \\
\text { noticeable. Part of the skin } \\
\text { was deep to moderate } \\
\text { purplish-red. }\end{array}$ & $\begin{array}{l}\text { The edema reduced. } \\
\text { The blanching was } \\
\text { evident in some areas. } \\
\text { The skin was mild } \\
\text { purplish-red. Crust was } \\
\text { formed on the skin. }\end{array}$ & $\begin{array}{l}\text { The edema was gone. } \\
\text { The blanching was evident } \\
\text { in some areas. The purplish- } \\
\text { red color faded. The scar was } \\
\text { formed. }\end{array}$ \\
\hline Group B & & $\begin{array}{c}\text { Mild edema occurred. } \\
\text { Blanching was observed } \\
\text { in part of the experimental } \\
\text { area. }\end{array}$ & $\begin{array}{c}\text { Edema was gone. } \\
\text { The blanching became } \\
\text { more evident. }\end{array}$ & $\begin{array}{l}\text { The blanched area } \\
\text { turned darker. }\end{array}$ & $\begin{array}{l}\text { The blanching reduced } \\
\text { significantly but the skin color } \\
\text { still looked a little different from } \\
\text { the normal skin color. }\end{array}$ \\
\hline Group C & & $\begin{array}{l}\text { Moderate to severe edema } \\
\text { occurred. The skin was deep } \\
\text { purplish-red. No blister was } \\
\text { formed. }\end{array}$ & $\begin{array}{l}\text { Both the edema and } \\
\text { the purplish-red color } \\
\text { were in a moderate level. }\end{array}$ & $\begin{array}{l}\text { The edema and } \\
\text { the purplish-red color } \\
\text { became mild. Blanching } \\
\text { was evident in some } \\
\text { areas. }\end{array}$ & $\begin{array}{l}\text { The edema and the purplish-red } \\
\text { color was gone. Blanching was } \\
\text { evident in some areas. No scar } \\
\text { was formed. }\end{array}$ \\
\hline Group D & & \multicolumn{4}{|c|}{ No noticeable changes were observed. } \\
\hline
\end{tabular}

\section{Collagen type I:IIl ratio in each group}

The collagen type I:III ratios in groups A1, A2, A3, B, and $C$ were similar to that in group $D$, while group $A 4$ had a higher ratio than group $\mathrm{D}(\mathrm{p}<0.05)$. This result indicates that the energy density in group A4 was too high and that it may cause a risk of fibrosis in the combs (Fig. 1).

\section{Response rate and adverse reactions in each group}

The results from groups A1-4 demonstrated that the response rate increased with the increase of energy density. In fact, the energy density of $175 \mathrm{~J} / \mathrm{cm}^{2}$ used in group A4 could easily cause blisters and scarring. Considering that NF usually occurs on the facial and neck area, any therapy that may lead to blisters and scarring in these areas is not suitable for clinical treatment. Thus, we chose an energy density of $150 \mathrm{~J} / \mathrm{cm}^{2}$ for further experiments. The results showed that group $C$ achieved a better response rate than groups A3 and B ( $p<0.05$ for both), and had a similar incidence rate of adverse reactions in comparison to groups A3 and B $(29.2 \%$ vs $29.2 \%, 29.2 \%$ vs $25.0 \%$; p > 0.05 for both; Tables 5,6 ).

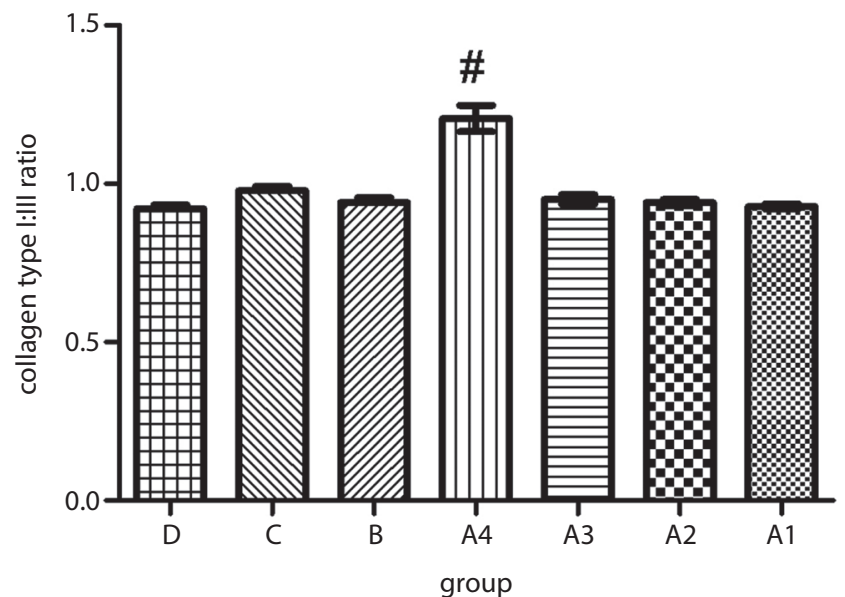

Fig. 1. Collagen fiber type I:III ratios in the experimental area of each group ( $\#<0.05$ vs group D)

\section{Discussion}

Methods for treating NF include surgical incision, cryotherapy with liquid nitrogen and skin grafting if the wound is large. ${ }^{19,20}$ However, these methods cannot achieve excellent results and are likely to cause scarring or pigmentation. 
Table 3. Results of microscopic observation in each group

\begin{tabular}{|c|c|c|c|c|c|}
\hline Group & Before treatment & 1 day after treatment & 3 days after treatment & 7 days after treatment & 14 days after treatment \\
\hline Group A1 & \multirow{6}{*}{$\begin{array}{l}\text { The epidermal } \\
\text { layer was intact. } \\
\text { Many dilated } \\
\text { capillaries } \\
\text { were observed } \\
\text { in the dermis. } \\
\text { Plenty of red blood } \\
\text { cells were present } \\
\text { in the vessels. }\end{array}$} & $\begin{array}{l}\text { Mild edema occurred } \\
\text { in the epidermal layer. Mild } \\
\text { exudation was observed } \\
\text { in the dermis. The number } \\
\text { of capillaries slightly } \\
\text { decreased. }\end{array}$ & $\begin{array}{l}\text { The edema } \\
\text { in the epidermal } \\
\text { layer slightly reduced. } \\
\text { Exudation in the dermis } \\
\text { still existed. The capillary } \\
\text { number and vessel } \\
\text { diameter decreased. }\end{array}$ & $\begin{array}{c}\text { Edema disappeared } \\
\text { in the epidermal layer. } \\
\text { Exudation in the dermis } \\
\text { reduced. }\end{array}$ & $\begin{array}{l}\text { There was no noticeable } \\
\text { edema or exudation. } \\
\text { The capillary number and } \\
\text { the vessel diameter reduced } \\
\text { slightly. }\end{array}$ \\
\hline Group A2 & & $\begin{array}{l}\text { Mild to moderate edema and } \\
\text { exudation occurred. A small } \\
\text { number of inflammatory cells } \\
\text { were observed. The number } \\
\text { of superficial capillaries } \\
\text { in dermis reduced. The vessel } \\
\text { diameter decreased. }\end{array}$ & $\begin{array}{l}\text { Edema and } \\
\text { exudation in dermis } \\
\text { were aggravated } \\
\text { a bit. The number } \\
\text { of inflammatory cells } \\
\text { increased a little. }\end{array}$ & $\begin{array}{c}\text { Edema and } \\
\text { exudation reduced } \\
\text { in the epidermal } \\
\text { and dermal layers. } \\
\text { The number } \\
\text { of inflammatory cells } \\
\text { reduced. }\end{array}$ & $\begin{array}{l}\text { No evident exudation } \\
\text { or edema was observed. } \\
\text { The number of inflammatory } \\
\text { cells reduced. The capillary } \\
\text { number decreased } \\
\text { significantly. The vessel } \\
\text { diameter reduced. }\end{array}$ \\
\hline Group A3 & & $\begin{array}{l}\text { Moderate to severe edema } \\
\text { and exudation occurred. } \\
\text { Many inflammatory cells } \\
\text { were observed. The capillary } \\
\text { number and the vessel } \\
\text { diameter reduced markedly. }\end{array}$ & $\begin{array}{l}\text { Edema and exudation } \\
\text { were aggravated. } \\
\text { The number } \\
\text { of inflammatory cells } \\
\text { increased. The capillary } \\
\text { number and the vessel } \\
\text { diameter reduced further. }\end{array}$ & $\begin{array}{l}\text { Edema and exudation } \\
\text { decreased. The number } \\
\text { of inflammatory cells } \\
\text { began to decline. } \\
\text { The capillary number } \\
\text { and the vessel diameter } \\
\text { reduced further. }\end{array}$ & $\begin{array}{l}\text { Edema and exudation } \\
\text { reduced markedly. } \\
\text { The number of inflammatory } \\
\text { cells reduced markedly. } \\
\text { The epidermal layer was } \\
\text { thickened. No blister was } \\
\text { formed. The capillary number } \\
\text { and the vessel diameter } \\
\text { reduced significantly. }\end{array}$ \\
\hline Group A4 & & $\begin{array}{l}\text { Severe edema and exudation } \\
\text { occurred. Blisters were } \\
\text { present in dermis. Infiltration } \\
\text { of many inflammatory cells } \\
\text { was observed. The capillary } \\
\text { number and the vessel } \\
\text { diameter reduced markedly. }\end{array}$ & $\begin{array}{l}\text { Edema and exudation } \\
\text { were aggravated. } \\
\text { The capillary number } \\
\text { and the vessel diameter } \\
\text { reduced further. }\end{array}$ & $\begin{array}{l}\text { Moderate to severe } \\
\text { edema and exudation } \\
\text { occurred. The number } \\
\text { of inflammatory cells } \\
\text { did not decrease } \\
\text { significantly. } \\
\text { The capillaries were } \\
\text { almost gone. }\end{array}$ & $\begin{array}{l}\text { Edema and exudation began } \\
\text { to decrease. Inflammatory } \\
\text { cells reduced. More capillaries } \\
\text { disappeared. Proliferative } \\
\text { collagen fibers were formed. }\end{array}$ \\
\hline Group B & & $\begin{array}{l}\text { Mild to moderate edema } \\
\text { and exudation occurred. } \\
\text { Few inflammatory cells } \\
\text { were present. The number } \\
\text { of superficial capillaries } \\
\text { in dermis reduced. The vessel } \\
\text { diameter decreased. }\end{array}$ & $\begin{array}{l}\text { Edema and } \\
\text { exudation in dermis } \\
\text { were aggravated } \\
\text { a little. The number } \\
\text { of inflammatory cells } \\
\text { increased. }\end{array}$ & $\begin{array}{l}\text { Edema and exudation } \\
\text { in epidermal and } \\
\text { dermal layer reduced } \\
\text { markedly. The number } \\
\text { of inflammatory cells } \\
\text { reduced markedly. }\end{array}$ & $\begin{array}{l}\text { No evident exudation } \\
\text { or edema was observed. } \\
\text { The inflammatory cells almost } \\
\text { disappeared. The capillary } \\
\text { number and the vessel } \\
\text { diameter reduced. }\end{array}$ \\
\hline Group C & & $\begin{array}{l}\text { Moderate to severe } \\
\text { exudation occurred. Many } \\
\text { inflammatory cells were } \\
\text { observed. The capillary } \\
\text { number and the vessel } \\
\text { diameter reduced markedly. }\end{array}$ & $\begin{array}{l}\text { Exudation and edema } \\
\text { were aggravated. } \\
\text { The number } \\
\text { of inflammatory cells } \\
\text { increased. Capillary } \\
\text { number and the vessel } \\
\text { diameter reduced further. }\end{array}$ & $\begin{array}{l}\text { Edema and exudation } \\
\text { decreased. The number } \\
\text { of inflammatory cells } \\
\text { decreased. Capillary } \\
\text { number and the vessel } \\
\text { diameter reduced } \\
\text { further. }\end{array}$ & $\begin{array}{l}\text { Edema and exudation } \\
\text { reduced markedly. } \\
\text { The number of inflammatory } \\
\text { cells reduced markedly. } \\
\text { The epidermal layer was } \\
\text { thickened. No blister was } \\
\text { formed. Capillaries almost } \\
\text { disappeared. }\end{array}$ \\
\hline Group D & & & No noticeable chan & ges were observed. & \\
\hline
\end{tabular}

Table 4 . Decrease in the number of capillaries $(\%, \pm S D)$

\begin{tabular}{|c|c|c|c|c|}
\hline Group & 1 day after treatment & 3 days after treatment & 7 days after treatment & 14 days after treatment \\
\hline Group A1 & $15.43 \pm 5.21^{\#}$ & $18.54 \pm 4.22^{\#}$ & $24.21 \pm 5.92^{\# \#}$ & 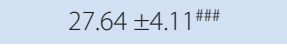 \\
\hline Group A2 & $25.67 \pm 6.31^{\# \#}$ & $31.88 \pm 4.23^{\# \# \#}$ & $37.23 \pm 5.43^{\# \# \#}$ & $40.21 \pm 4.37^{\# \# \#}$ \\
\hline Group A3 & $43.65 \pm 5.26^{\# \# \# *}$ & $59.35 \pm 4.77^{\# \# \# *}$ & $74.68 \pm 5.43^{\# \# \# *}$ & 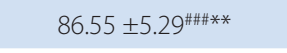 \\
\hline Group A4 & 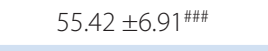 & $70.67 \pm 4.16^{\# \# \#}$ & $87.37 \pm 6.15^{\# \# \#}$ & $93.23 \pm 5.54^{\# \# \#}$ \\
\hline Group B & $26.44 \pm 4.25^{\# \# * *}$ & $32.17 \pm 4.16^{\# \# \# * * *}$ & $40.51 \pm 5.24^{\# \# \# * * *}$ & $45.33 \pm 4.65^{\# \# \# * * *}$ \\
\hline Group C & $52.87 \pm 4.69^{\# \# \#}$ & $68.53 \pm 5.21^{\# \# \#}$ & $86.33 \pm 6.89^{\# \# \#}$ & $94.25 \pm 4.11^{\# \# \#}$ \\
\hline Group D & $1.22 \pm 3.54$ & $1.34 \pm 3.61$ & $2.11 \pm 2.24$ & $1.18 \pm 3.85$ \\
\hline
\end{tabular}

Compared with Group D: $p<0.05,{ }^{\# \#} p<0.01,{ }^{\# \# \#} p<0.001$; compared with Group C: ${ }^{*} p<0.05,{ }^{* *} p<0.01,{ }^{* * *} p<0.001$. 
Table 5. Efficacy in each group

\begin{tabular}{|l|c|c|c|c|c|c|}
\multicolumn{1}{|c|}{ Group } & $\begin{array}{c}\text { Excellent } \\
\text { response }\end{array}$ & $\begin{array}{c}\text { Good } \\
\text { response }\end{array}$ & Fair response & Poor response & No response & Total response rate [\%] \\
\hline Group A1 & 0 & 0 & 2 & 3 & 1 & 33.3 \\
\hline Group A2 & 0 & 2 & 1 & 2 & 1 & 50.0 \\
\hline Group A3 & 3 & 2 & 0 & 1 & 0 & $83.3^{\# *}$ \\
\hline Group A4 & 5 & 1 & 0 & 0 & 0 & $100.0^{* *}$ \\
\hline Group B & 0 & 2 & 2 & 1 & 1 & $66.7^{\# \#}$ \\
\hline Group C & 6 & 0 & 0 & 0 & 0 & 100 \\
\hline
\end{tabular}

Compared with Group C: ${ }^{\#} p<0.05$, ${ }^{\# \#} p<0.01$; compared with Group B: ${ }^{*} p<0.05$, ${ }^{* *} p<0.01$.

Table 6. Adverse reactions in each group

\begin{tabular}{|l|c|c|c|}
\hline \multicolumn{1}{|c|}{ Variable } & Blister & Scar & Pigmentation \\
\hline Group A1 & 0 & 0 & 0 \\
\hline Group A2 & 0 & 0 & 1 \\
\hline Group A3 & 0 & 0 & 3 \\
\hline Group A4 & 5 & 6 & 6 \\
\hline Group B & 0 & 0 & 4 \\
\hline Group C & 1 & 0 & 3 \\
\hline P-value & $<0.001$ & $<0.001$ & 3 \\
\hline$X^{2}$ & 23.546 & 25.264 & $<$ \\
\hline
\end{tabular}

$x^{2}-$ chi-squared test

Therefore, it is essential to find a safer and more effective method for treating NF. In recent years, PDT and variable pulse width Nd:YAG lasers have often been employed in clinical practice. The PDT can achieve good results for treating superficial vascular lesions, but not for deep vascular malformations, due to its weak laser penetration. In contrast, variable pulse width Nd:YAG lasers, with stronger laser penetration, can treat the capillary malformations in deep tissues. ${ }^{15,21}$ Therefore, in order to effectively treat both superficial and deep vascular malformations in NF, we investigated the effect of a combination therapy of PDT and a variable pulse width Nd:YAG laser.

We found that in the PDT groups, the clearance improved with increased energy density, and that PDT at an energy density of $175 \mathrm{~J} / \mathrm{cm}^{2}$ achieved the highest clearance rate. However, the group with this energy density had the most adverse reactions, including severe blistering and scarring, and had markedly higher collagen type I:III ratios, suggesting the potential risk, or even the presence, of fibrosis in the combs. ${ }^{22}$ Therefore, an energy density of $175 \mathrm{~J} / \mathrm{cm}^{2}$ cannot be employed clinically; instead, $150 \mathrm{~J} / \mathrm{cm}^{2}$ may be considered a suitable energy density. The PDT at $150 \mathrm{~J} / \mathrm{cm}^{2}$ in group A3 was found to achieve a good clearance rate and a similar incidence rate of adverse reactions as found in groups B and C; likewise, PDT at this energy density did not cause a noticeable elevation in the collagen type I:III ratio, indicating a low risk of fibrosis.

In this study, we found that the combination of PDT and a variable pulse width Nd:YAG laser was able to achieve a better outcome than PDT or variable pulse width Nd:YAG laser alone. The combination therapy achieved a similar response rate with a lower incidence of adverse reactions in comparison with the PDT therapy at $175 \mathrm{~J} / \mathrm{cm}^{2}$. The combined use of PDT and a variable pulse width Nd:YAG laser can treat both deep and superficial capillary malformations. So far, many scholars have explored the combination of 2 or more therapies for treating NF, including cryotherapy combined with laser therapy, surgery combined with laser therapy, microneedle therapy combined with PDT, and pulsed dye laser therapy combined with long-pulse 1064-nm Nd:YAG laser therapy. However, many of these methods can easily cause adverse reactions, including scarring and pigmentation. The combination of microneedle therapy and PDT, even though it can achieve good outcomes, requires a more complicated operation than the combination of PDT and a variable pulse width Nd:YAG laser. Therefore, the combined use of PDT and variable pulse width Nd:YAG laser therapy can be recommended for further clinical trials.

Due to time constraints, there were some limitations in our study. Firstly, there are still some differences between cockscomb skin and human skin, even though the cockscomb can be used as a disease model of NF. Secondly, since human facial skin is more delicate, whether PDT at $150 \mathrm{~J} / \mathrm{cm}^{2}$ can be used to treat faces needs to be investigated further. In this study, we found that the combination of 2 therapies, even though it did not increase the incidence of adverse reactions, could still lead to blisters and scars on the subjects. 
Therefore, we do not recommend its clinical application on facial areas to avoid scarring or other adverse reactions. Lastly, the study only demonstrated the short-term effect within 14 days of treatment, and more studies need to be carried out in the future to investigate the adverse reactions and recurrence rate after a longer course of treatment.

\section{Conclusions}

In conclusion, $150 \mathrm{~J} / \mathrm{cm}^{2}$ can serve as a suitable energy density in PDT for the treatment of NF, and the combination of HMME-mediated PDT and variable pulse width Nd:YAG laser therapy can achieve a better outcome than PDT or such a laser alone, so it can be recommended for clinical application.

\section{ORCID iDs}

Ke Ma (1) https://orcid.org/0000-0002-7982-5536

Jinmin Zhao (1) https://orcid.org/0000-0002-4341-9317

Lvjun Yang (1) https://orcid.org/0000-0002-9300-0549

Mingde Liao (1) https://orcid.org/0000-0001-5499-3106

Yi Qin (1) https://orcid.org/0000-0002-7039-4549

Chao Luo (1) https://orcid.org/0000-0003-1943-6659

Lina Lin (1) https://orcid.org/0000-0001-8106-568X

Danyan Ye (1D) https://orcid.org/0000-0003-0482-4085

\section{References}

1. Sharma M, Hu X, Geddes GC, Acharya K. Microcephalic newborn with forehead nevus flammeus, bulging eyes, and clenched fists. Neoreviews. 2019;20(3):e170-e173. doi:10.1542/neo.20-3-e170

2. Takkar B, Saxena H, Sharma B, Rathi A. Generalised nevus flammeus, episcleral capillary malformation and glaucoma. BMJ Case Rep. 2018; 2018:bcr2018227248. doi:10.1136/bcr-2018-227248

3. Shruti S, Siraj F, Ramesh V, Ramesh V. Recurrent pyogenic granuloma over nevus flammeus. Indian J Dermatol Venereol Leprol. 2019;85(2): 236-236. doi:10.4103/ijdvl.IJDVL_80_17

4. Combalia A, Rojano-Fritz L, Podlipnik S, Ferrando J. Nuchal nevus flammeus and alopecia areata: When size matters. Int J Trichology. 2018;10(6):275-277. doi:10.4103/ijt.ijt 8218

5. Burns JM, Jia W, Nelson JS, Majaron B, Anvari B. Photothermal treatment of port-wine stains using erythrocyte-derived particles doped with indocyanine green: A theoretical study. J Biomed Opt. 2018; 22(12):121616. doi:10.1117/1.JBO.23.12.121616

6. Yu W, Zhu J, Wang L, et al. Double pass $595 \mathrm{~nm}$ pulsed dye laser does not enhance the efficacy of port wine stains compared with single pass: A randomized comparison with histological examination. Photomed Laser Surg. 2018;36(6):305-312. doi:10.1089/pho.2017.4392
7. Lipner SR. Topical adjuncts to pulsed dye laser for treatment of port wine stains: Review of the literature. DermatolSurg. 2018;44(6):796-802. doi:10.1097/DSS.0000000000001507

8. Lin L, Guo P, Wang X, et al. Effective treatment for hypertrophic scar with dual-wave-length PDL and Nd:YAG in Chinese patients. J Cosmet Laser Ther. 2019;21(4):228-233. doi:10.1080/14764172.2018.1516889

9. Zhang $Y$, Yang $Y$, Zhang Z, et al. Clinical study on hemoporfin PDT for infant facial port-wine stains. Photodiagnosis Photodyn Ther. 2019; 25:106-110. doi:10.1016/j.pdpdt.2018.09.012

10. Wen $L$, Zhang $Y$, Zhang $L$, et al. Application of different noninvasive diagnostic techniques used in HMME-PDT in the treatment of port wine stains. Photodiagnosis Photodyn Ther. 2019;25:369-375. doi:10.1016/j.pdpdt.2019.01.008

11. Wang Y, Liao X-H, Gu Y, Chen R, Zeng J. The change of reflection spectra and fluorescence spectra of port wine stains during PDT [in Chinese]. Guang Pu Xue Yu Guang Pu Fen Xi. 2011;31(1):2969-2972.

12. Huang NY. What is the optimal PDT protocol for treating port wine stains (PWS)? Photodiagnosis Photodyn Ther. 2007;4:145-146. doi:10. 1016/j.pdpdt.2007.07.005

13. Gu Y, Huang NY, Liang J, Pan YM, Liu FG. Clinical study of 1949 cases of port wine stains treated with vascular photodynamic therapy (Gu's PDT) [in French]. Anna Dermatol de Venereol. 2007;134(3 Pt 1): 241-244. doi:10.1016/s0151-9638(07)91816-5

14. Abdul Latif AA, Abdel-Hameed AKS, Salama OAAM. Immediate postirradiation dermoscopic vascular changes versus purpura as a therapeutic endpoint in pulsed-dye laser treatment of port wine stains. Dermatol Ther. 2019:32(6):e13094-e13094. doi:10.1111/dth.13094

15. Xing L, Chen B, Li D, Wu W, Wang G. Nd:YAG laser combined with gold nanorods for potential application in port-wine stains: An in vivo study. J Biomed Opt. 2017;22(11):1-10. doi:10.1117/1.JBO.22.11.115005

16. Chang HS, Kim Y-G, Lee JH. Treatment using a long pulsed nd:yag laser with a pulsed dye laser for four cases of blebbed port wine stains. Ann Dermatol. 2011;23(Suppl 1):S75-S78. doi:10.5021/ad.2011. 23.S1.S75

17. Cong T, Liu L, Zhang H, Wang L, Jiang X. Port-wine stains associated with large vestibular aqueduct syndrome caused by mutations in GNAQ and SLC26A4 genes: A case report. J Dermatol. 2020;47:78-81. doi:10.1111/1346-8138.15130

18. Stephens MR, Putterman E, Yan AC, Castelo-Soccio L, Perman MJ. Acquired port-wine stains in six pediatric patients. Pediatr Dermatol. 2020;37(1):93-97. doi:10.1111/pde.14019

19. Mathes EF, Frieden IJ. Early use of laser for port-wine stains: Timing, efficacy, and shared decision-making. JAMA Dermatol. 2019;155(4): 421-423. doi:10.1001/jamadermatol.2018.5189

20. Jeon H, Bernstein LJ, Belkin DA, Ghalili S, Geronemus RG. Pulsed dye laser treatment of port-wine stains in infancy without the need for general anesthesia. JAMA Dermatol. 2019;155(4):435-441. doi:10.1001/ jamadermatol.2018.5249

21. Pençe B, Aybey B, Ergenekon G. Outcomes of $532 \mathrm{~nm}$ frequencydoubled Nd:YAG laser use in the treatment of port-wine stains. Dermatol Surg. 2005;31(5):509-517. doi:10.1111/j.1524-4725.2005.31152

22. Lorenz $S$, Scherer $K$, Wimmershoff MB, Landthaler M, Hohenleutner U. Variable pulse frequency-doubled Nd:YAG laser versus flashlamppumped pulsed dye laser in the treatment of port wine stains. Acta Derm Venereol. 2003;83(3):210-213. doi:10.1080/00015550310007238 